\title{
On the Revolutions of Space
}

\author{
Megan Gannon
}

(In Which Jane Dudley's Mistaken Cosmology

Reveals her True Intent to Queen Mary)

Good madam, of goodness

remember me. How like some

celestial body I have kept to this

fixed circumference, skirting

in my skirts the sphere

of influence. Majesty, I have been

as hoops in a farthingale, encircling

and concealing from prying eyes

the deeds of three queens.

Some had sought to overstep

this distance, an idea

as disallowed as sun supplanting

earth at heaven's core.

If once I positioned myself

closer to the body corporate, it was only as laces tightened about flesh wedded to my flesh, a pressure that stifles less than fortifies the spine. Would I were free of these changing fashions, that admiring lights might warm without drawing close. Lady, I burn in the balance; your oscillations agitate oceans in ebb and flood.

Would I knew the formula for these tides. 